\section{Nauplius}

The JOURnAL OF The

Brazilian Crustacean Society

e-ISSN 2358-2936

www.scielo.br/nau www.crustacea.org.br

\title{
New records of two species of freshwater crabs (Decapoda: Gecarcinucidae) from Kerala, India, with notes on their distribution
}

S.K. Pati ${ }^{1}$ (D) orcid.org/0000-0001-8418-7500

P.S. Sujila ${ }^{2}$ (D) orcid.org/0000-0002-2072-5661

A.R. Sudha Devi ${ }^{2}$ (D) orcid.org/0000-0003-4062-8073

1 Zoological Survey of India, Western Regional Centre. Vidyanagar, Sector 29, P.C.N.T. Post, Akurdi, Pune-411 044, Maharashtra, India.

SKP E-mail: sameer_pati@yahoo.co.in

2 Department of Zoology and Research Centre, Mary Matha Arts and Science College. Vemom P.O., Mananthavady-670 645, Kerala, India.

PSS E-mail: jnips333@gmail.com

ARSD E-mail: arsudhadevi@gmail.com

ZOOBANK: http://zoobank.org/urn:lsid:zoobank.org:pub:5EA8DFEA-7C17-4F738DB0-AD87CB332811

\section{ABSTRACT}

Kerala has the highest known diversity of freshwater crabs among the Indian states, and many more species are likely to be added to the state, especially from the Western Ghats. The present specimens from the Western Ghats of Kerala add two more species records to Kerala: Oziotelphusa wagrakarowensis (Rathbun, 1904) and Vanni nilgiriensis (Roux, 1931). Although O. wagrakarowensis was reported from the Indian states of Andhra Pradesh, Karnataka, and Maharashtra, it has not been recorded from Kerala previously. The present record of $O$. wagrakarowensis also constitutes the first reliable report of the species from the Western Ghats. The other species, V. nilgiriensis, was previously known from the Western Ghats of Karnataka and Tamil Nadu. Kerala now includes 37 species of gecarcinucid crabs with the addition of these two new records whereas the Western Ghats of India currently has 59 species.

\section{KeYwords}

Crustacea, Brachyura, Oziotelphusa, Vanni, Western Ghats.

CORRESPONDING AUTHOR S. K. Pati

sameer_pati@yahoo.co.in

SUBMITTED 26 Jan 2019 ACCEPTED 15 April 2019 PUBLISHED 23 May 2019

DOI 10.1590/2358-2936e2019006

\section{(cc) BY}

All content of the journal, except where identified, is licensed under a Creative Commons attribution-type BY.

Nauplius, 27: e2019006 
Despite the high diversity of freshwater crabs in Kerala, many parts of the state, especially the Western Ghats, are still poorly explored for their diversity. One possible reason for this is the remoteness of these localities. Considering the small spatial scale of endemism in freshwater crabs (Klaus et al., 2014), more isolated and poorly studied areas need to be investigated. Furthermore, many new taxa await descriptions as evident from the recent discoveries (Pati and Sharma, 2013; Pati and Sudha Devi, 2015a; 2015b; Kumar et al., 2017; Pati et al., 2017).

During the present study, specimens were collected from the Western Ghats of Wayanad district in Kerala. These specimens belong to two species that have not been reported from Kerala previously: Oziotelphusa wagrakarowensis (Rathbun, 1904) and Vanni nilgiriensis (Roux, 1931).

Oziotelphusa wagrakarowensis has so far been reported from the states of Andhra Pradesh (Rathbun, 1904; Bott, 1970a; Bahir and Yeo, 2005), Karnataka (Bahir and Yeo, 2005; Srivastava, 2007; 2013; Pati and Sharma, 2014), and Maharashtra (Pati and Sharma, 2012a; 2014). Most of the specimens from Karnataka (ZSI-WRC C.445, 449, 456, 563-565) reported as O. senex senex (Fabricius, 1798) by Srivastava (2013) were already assigned to $O$. wagrakarowensis by Pati and Sharma (2014). In this situation, all the specimens of $O$. senex senex examined by Srivastava (2013), and probably by Srivastava (2007), are likely to be conspecific with $O$. wagrakarowensis. Oziotelphusa wagrakarowensis has been reported from rather elevated areas (350-950 m altitude) of the Indian peninsula, including the Western Ghats mountains. It was recorded from the Western Ghats at the Bannerghatta National Park of Bangalore Urban district, Bandipur Tiger Reserve of Chamarajanagar district, and Hosur of Uttara Kannada district (see Srivastava, 2007; 2013; Pati and Sharma, 2014). The species, however, was never included in the Western Ghats fauna (see Pati and Thackeray, 2018). The present specimens of $O$. wagrakarowensis from Wayanad district of Kerala, therefore, constitute the first reliable report of the species from the Western Ghats. On the other hand, $V$. nilgiriensis has only been recorded from Karnataka (Pati and Sureshan, unpublished data) and Tamil Nadu (Roux, 1931; Bott, 1970a; 1970b; Bahir and Yeo, 2007; Srivastava, 2009; Klaus et al., 2014).
With the addition of these two new records, Kerala has 37 species of gecarcinucid crabs, including four species of Oziotelphusa Müller, 1887 and six species of Vanni Bahir and Yeo, 2007. The Western Ghats of India is now known to have 59 freshwater crab species in 18 genera (Pati and Thackeray, 2018).

The terminology is mainly after $\mathrm{Ng}$ (1988), with changes following Davie et al. (2015). All the present material is deposited at the Zoological Survey of India, Western Regional Centre, Pune, India (ZSIWRC). The comparative material is from ZSI-WRC and the Zoological Survey of India, Western Ghats Regional Centre, Kozhikode, India (ZSI-WGRC). The abbreviations used are as follows: cw, carapace width; cl, carapace length; ch, carapace height; fw, frontal width; coll. collected by; $\mathrm{s} 2$, thoracic sternite 2; s3, thoracic sternite 3; s4, thoracic sternite 4; G1, male first gonopod; G2, male second gonopod.

\section{Family Gecarcinucidae Rathbun, 1904}

\section{Oziotelphusa wagrakarowensis (Rathbun, 1904)} (Fig. 1)

Potamon (Potamon) wagrakarowensis Rathbun, 1904: 292.

Paratelphusa (Oziotelphusa) hydrodromus - Alcock, 1910: 97 (part; not Cancer hydrodromus Herbst, 1794).

Oziotelphusa senex senex - Bott, 1970a: 100 (part; not Cancer senex Fabricius, 1798).

Oziotelphusa wagrakarowensis - Bahir and Yeo, 2005: 87. - Ng et al., 2008 (list): 70. — Pati and Sharma, 2012a: 126 (list). _ Pati and Sharma, 2012b: 365 (list). - Pati and Sharma, 2014: 35.

Oziotelphusa senex senex - Srivastava, 2007: 35 (not Cancer senex Fabricius, 1798). — Srivastava, 2013: 77 (not Cancer senex Fabricius, 1798).

Material examined. INDIA. Kerala: Wayanad district - 4 males (cw 29.18-33.92 mm, cl 20.76-22.20 mm, ch $14.35-15.81 \mathrm{~mm}$, fw 8.91-9.15 mm) and 1 female (cw $32.50 \mathrm{~mm}, \mathrm{cl} 22.28 \mathrm{~mm}$, ch $17.21 \mathrm{~mm}$, fw 9.67 $\mathrm{mm})$, Ondayangadi, near Mananthavady $\left(11.823^{\circ} \mathrm{N}\right.$, $76.026^{\circ} \mathrm{E}$; altitude $\left.767 \mathrm{~m}\right), 17$ September 2018, coll. Ammini (ZSI-WRC C.1830). 


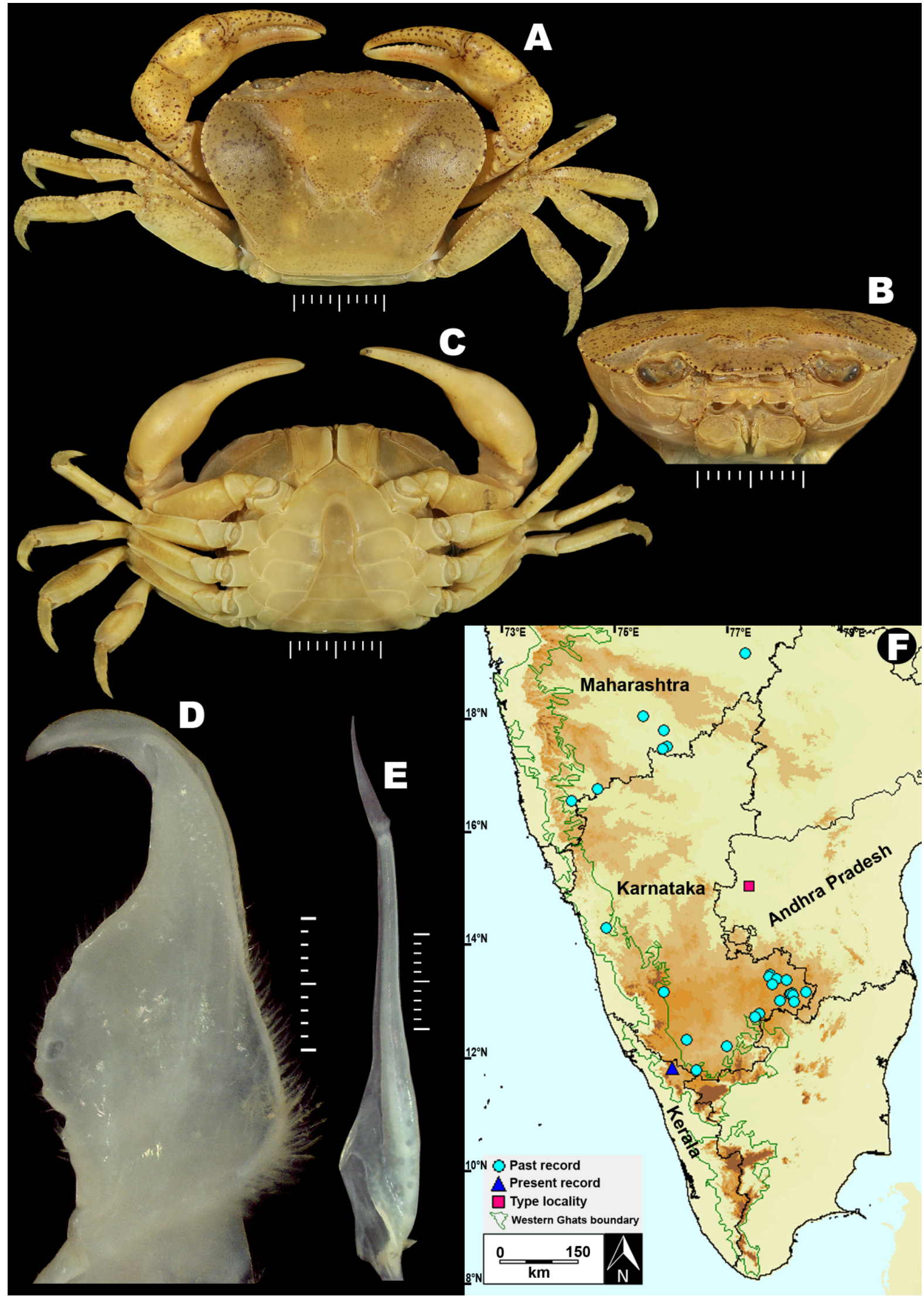

Figure 1. Oziotelphusa wagrakarowensis (Rathbun, 1904), male $(29.18 \times 20.76 \mathrm{~mm})($ ZSI-WRC C.1830). A, overall dorsal view; B, frontal view of cephalothorax; C, overall ventral view; D, dorsal view of left G1; E, left G2; F, map showing distribution of $O$. wagrakarowensis in the Indian peninsula. Scale bar $=10 \mathrm{~mm}(\mathrm{~A}-\mathrm{C}), 1 \mathrm{~mm}(\mathrm{D}, \mathrm{E})$. 
Comparative material. INDIA. Karnataka: Bangalore Rural district -7 males and 3 females, Vijayapura Tank, Vijayapura $\left(13.295^{\circ} \mathrm{N}, 77.801^{\circ} \mathrm{E}\right.$; altitude 885 m), 19 March 1978, coll. M. Babu Rao et al. (ZSIWRC C.451). Chamarajanagar district - 3 males and 2 females, Pdoddane Katte and Karigondu Katte, Bandipur Tiger Reserve $\left(11.769^{\circ} \mathrm{N}, 76.448^{\circ} \mathrm{E}\right.$; altitude 839 m), 21 September 1989, coll. G.M. Yazdani (ZSIWRC C.606). Chikballapura district -8 males and 2 females, Kanepalli Tank, Chintamani $\left(13.381^{\circ} \mathrm{N}\right.$, $78.037^{\circ} \mathrm{E}$; altitude $\left.882 \mathrm{~m}\right), 13 \mathrm{March} 1978$, coll. M. Babu Rao et al. (ZSI-WRC C.457); 6 males and 1 female, Gavana Tank, Siddalghata $\left(13.392^{\circ} \mathrm{N}\right.$, $77.865^{\circ} \mathrm{E}$; altitude $\left.890 \mathrm{~m}\right), 15$ March 1978 , coll. M. Babu Rao et al. (ZSI-WRC C.566); 7 males, Appayya Kunta, Chikballapura $\left(13.426^{\circ} \mathrm{N}, 77.730^{\circ} \mathrm{E}\right.$; altitude 905 m), 17 March 1978, coll. M. Babu Rao et al. (ZSIWRC C.449); 12 males and 9 females, Manchanpani Tank, Chikballapura $\left(13.464^{\circ} \mathrm{N}, 77.747^{\circ} \mathrm{E}\right.$; altitude 904 m), 18 March 1978, coll. M. Babu Rao et al. (ZSIWRC C.565). Kolar district - 11 males and 5 females, Malekar Tank, Katerpalem $\left(13.136^{\circ} \mathrm{N}, 78.133^{\circ} \mathrm{E}\right.$; altitude 837 m), 3 March 1978, coll. M. Babu Rao et al. (ZSI-WRC C.445); 6 males and 12 females, Malekar Tank, Katerpalem $\left(13.136^{\circ} \mathrm{N}, 78.133^{\circ} \mathrm{E}\right.$; altitude 837 m), 4 March 1978, coll. M. Babu Rao et al. (ZSI-WRC C.567); 3 males and 1 female, Malur Tank, Malur $\left(13.007^{\circ} \mathrm{N}, 77.927^{\circ} \mathrm{E}\right.$; altitude $\left.898 \mathrm{~m}\right), 5$ March 1978 , coll. M. Babu Rao et al. (ZSI-WRC C.450); 9 males, Abdul Ali Garden, Bangarpet $\left(12.993^{\circ} \mathrm{N}, 78.179^{\circ} \mathrm{E}\right.$; altitude $824 \mathrm{~m}$ ), 6 March 1978, coll. M. Babu Rao et al. (ZSI-WRC C.564); 28 males and 7 females, Mashid Basalguntha Tank, Mulbagal $\left(13.162^{\circ} \mathrm{N}, 78.390^{\circ} \mathrm{E}\right.$; altitude $839 \mathrm{~m}$ ), 8 March 1978, coll. M. Babu Rao et al. (ZSI-WRC C.444); 9 males and 2 females, Dodda Hassala Lake, Dodda Hassala $\left(13.099^{\circ} \mathrm{N}, 78.166^{\circ} \mathrm{E}\right.$; altitude $812 \mathrm{~m}$ ), 10 March 1978, coll. M. Babu Rao et al. (ZSI-WRC C.563). Uttara Kannada district - 6 males and 15 females, Hosur, Siddapur $\left(14.295^{\circ} \mathrm{N}\right.$, $74.853^{\circ} \mathrm{E}$; altitude $\left.583 \mathrm{~m}\right), 18$ September 1991 , coll. R.M. Sharma et al. (ZSI-WRC C.456).

Maharashtra: Kolhapur district - 1 male, Nadi Kinara, Vannur $\left(16.546^{\circ} \mathrm{N}, 74.243^{\circ} \mathrm{E}\right.$; altitude 527 m), 13 September 2012, coll. S.S. Kamble (ZSI-WRC C.1084). Nanded district -2 males and 2 females, Kabarali $\left(19.153^{\circ} \mathrm{N}, 77.306^{\circ} \mathrm{E}\right.$; altitude $\left.355 \mathrm{~m}\right), 16$ August 1971, coll. K.R. Rao (ZSI-WRC C.1002).
Sangli district -2 males, Mhaisal, approximately $15 \mathrm{~km}$ from Miraj $\left(16.752^{\circ} \mathrm{N}, 74.704^{\circ} \mathrm{E}\right.$; altitude 537 m), 27 September 1984, coll. A.S. Mahabal et al. (ZSIWRC C.916). Solapur district - 3 males, Sind River, near Sindkhed $\left(17.501^{\circ} \mathrm{N}, 75.930^{\circ} \mathrm{E}\right.$; altitude $\left.407 \mathrm{~m}\right)$, 22 November 1978, coll. A.S. Mahabal (ZSI-WRC C.803); 1 male, Nagamma Tank, on Vizapur road $\left(17.460^{\circ} \mathrm{N}, 75.851^{\circ} \mathrm{E}\right.$; altitude $\left.441 \mathrm{~m}\right), 24$ November 1978, coll. A.S. Mahabal (ZSI-WRC C.810); 2 males and 4 females, Pimpaldara Nalla, near Padasali-Madha $\left(18.030^{\circ} \mathrm{N}, 75.508^{\circ} \mathrm{E}\right.$; altitude $\left.488 \mathrm{~m}\right), 24$ August 1983 , coll. A.S. Mahabal (ZSI-WRC C.809); 1 male and 1 female, Banegaon, near Nannaj, Great Indian Bustard Sanctuary $\left(17.777^{\circ} \mathrm{N}, 75.882^{\circ} \mathrm{E}\right.$; altitude $\left.483 \mathrm{~m}\right), 4$ October 2011, coll. P.S. Bhatnagar et al. (ZSI-WRC C.521).

Diagnosis. Carapace broader than long $(\mathrm{cw} / \mathrm{cl}=$ $1.4-1.5)$, moderately deep $(\mathrm{ch} / \mathrm{cw}=0.5)$; dorsal surface distinctly convex fore and aft; frontal median triangle complete, not as broad as frontal margin; epigastric and postorbital cristae well developed; external orbital angle triangular, with short outer margin, approximately 2 times length of inner margin; epibranchial tooth moderate in size, sharp; branchial regions moderately inflated; epistomal median lobe with distinct, sharp median tooth (Fig. 1A, B). Suture between male thoracic sternites $\mathrm{s} 2 / \mathrm{s} 3$ indistinct; suture between male thoracic sternites $\mathrm{s} 3 / \mathrm{s} 4$ visible as groove medially, not reaching edge of sternum (Fig. 1C). Male pleon narrowly triangular, with strongly concave lateral margins; pleonal somite 6 trapezoidal, slightly broader than long, as long as telson, with strongly concave lateral margins (Fig. 1C). G1 highly stout, with downwardly curved, hook-like terminal segment; terminal segment subcylindrical, short, approximately 0.3-0.4 times length of subterminal segment, tip subacute; subterminal segment highly stout (Fig. 1D). G2 longer than G1, approximately 1.1-1.2 times length of G1; distal segment short, approximately $0.2-0.3$ times length of basal segment (Fig. 1E).

Remarks. Bahir and Yeo (2005) noted that the G1 terminal segment of $O$. wagrakarowensis is about 0.3 times the length of the subterminal segment. The male lectotype of O. wagrakarowensis from Andhra Pradesh, however, has a slightly longer G1 terminal 
segment (approximately $0.4 \times$ length of the subterminal segment) (see Bahir and Yeo, 2005: fig. 12C). The present specimens from Wayanad districts of Kerala also have a long $\mathrm{G} 1$ terminal segment, approximately 0.4 times the length of the subterminal segment (Fig. 1D). While our specimens resemble the lectotype in most of the carapace features, they only differ in the relative length between $\mathrm{G} 2$ and $\mathrm{G} 1$, i.e., the $\mathrm{G} 2$ length is about 1.2 times the length of the G1 (Fig. 1D, E) (vs. the G2 length is about 1.1 times the length of the $\mathrm{G} 1$; see Bahir and Yeo, 2005: fig. 12C, E). Other comparative material from Karnataka and Maharashtra also showed the following small variations: the G1 terminal segment is about 0.3-0.4 times the length of the subterminal segment; the G2 length is about 1.1-1.2 times the length of the G1; and the G2 distal segment is about $0.2-0.3$ times the length of the basal segment. These small variations may be due to the differences in size (cw 17.30-37.92 mm) and age of the crabs.

Geographical distribution. Oziotelphusa wagrakarowensis is currently known from Andhra Pradesh (Anantapur district), Karnataka (Bangalore Rural, Bangalore Urban, Chamarajanagar, Chikballapura, Hassan, Kolar, Mysore, and Uttara Kannada districts), Kerala (Wayanad district), and Maharashtra (Kolhapur, Nanded, Sangli, and Solapur districts) of the Indian peninsula (Fig. 1F). The precise geographic range of $O$. wagrakarowensis is difficult to understand based on the known locality records. The species, however, seems to be restricted only to the highlands of the Deccan plateau and the Central Western Ghats. The wider distribution of $O$. wagrakarowensis in the highlands of the Indian peninsula - unlike the congeners with a relatively restricted distribution in lowland areas - could be associated with the geological history of the Deccan plateau and the formation of the Western Ghats. In fact, the Western Ghats are not true mountains but are faulted edge of the upraised Deccan plateau (Kuriakose and Sebastian, 2016). It is possible that $O$. wagrakarowensis was actually present in the Deccan plateau and later able to occupy some parts of the Western Ghats. Furthermore, the anthropogenic introduction of the species to newer localities cannot be overlooked since these crabs are generally associated with rice crops. If this is true, then these crabs might have been introduced to further south of Kerala as well.
In these situations, more surveys need to be conducted in the remaining part of Kerala.

\section{Vanni nilgiriensis (Roux, 1931)}

(Fig. 2)

Paratelphusa (Liotelphusa) nilgiriensis Roux, 1931: 56. Gubernatoriana nilgiriensis - Bott, 1970a: 45. — Bott, 1970b: 336. - Srivastava, 2009: 29 (list).

Vanni nilgiriensis - Bahir and Yeo, 2007: 341. - Ng et al., 2008: 68 (list) . — Dev Roy, 2012: 187 (list).

Material examined. INDIA. Kerala: Wayanad district - 1 male (cw $15.56 \mathrm{~mm}$, cl $11.35 \mathrm{~mm}$, ch $6.56 \mathrm{~mm}$, fw $4.94 \mathrm{~mm}$ ) and 3 females (cw 14.30-16.78 $\mathrm{mm}, \mathrm{cl}$ $10.43-12.11 \mathrm{~mm}$, ch $5.87-7.11 \mathrm{~mm}$, fw $4.72-5.29 \mathrm{~mm}$ ), Kambamala $\left(11.869^{\circ} \mathrm{N}, 75.942^{\circ} \mathrm{E}\right.$; altitude $\left.816 \mathrm{~m}\right), 26$ October 2018, coll. P.S. Sujila (ZSI-WRC C.1825); 4 males (cw 13.38-18.34 mm, cl 9.80-12.60 mm, ch $5.83-8.37 \mathrm{~mm}$, fw $4.24-5.46 \mathrm{~mm}$ ) and 9 females (cw 14.62-19.08 mm, cl 10.55-13.29 mm, ch 6.41-8.10 $\mathrm{mm}, \mathrm{fw} 4.62-5.95 \mathrm{~mm})$, Pilakavu $\left(11.867^{\circ} \mathrm{N}, 75.985^{\circ} \mathrm{E}\right.$; altitude $859 \mathrm{~m}$ ), 9 October 2018, coll. P.S. Sujila (ZSIWRC C.1826).

Comparative material. INDIA. Karnataka: Kodagu district - 1 male (cw $24.42 \mathrm{~mm}$, cl $17.24 \mathrm{~mm}$, ch 9.28 $\mathrm{mm}$, fw $7.99 \mathrm{~mm})$, Ezhilaturn, Thalacauveri Wildlife Sanctuary $\left(12.384^{\circ} \mathrm{N}, 75.494^{\circ} \mathrm{E}\right.$; altitude $\left.1185 \mathrm{~m}\right), 6$ November 2013, coll. P.M. Sureshan (ZSI-WGRC IR/INV/9197).

Diagnosis. Carapace broader than long $(\mathrm{cw} / \mathrm{cl}=$ 1.4-1.5), low ( $\mathrm{ch} / \mathrm{cw}=0.4)$; epigastric cristae distinct, slightly anterior to postorbital cristae; postorbital cristae rugose, not reaching epibranchial tooth; external orbital angle broadly triangular, with long outer margin, approximately 4-5 times length of inner margin; epibranchial tooth low, blunt; epistomal median lobe lacking median tooth (Fig. 2A, B). Ambulatory legs short, stout (Fig. 2A, C). Suture between male thoracic sternites s2/s3 visible as narrow groove, reaching lateral margins; suture between male thoracic sternites $\mathrm{s} 3 / \mathrm{s} 4$ only visible as 2 short lateral grooves (Fig. 2C). Male pleon moderately broad, almost triangular; pleonal somite 6 trapezoidal, broader than long, slightly shorter than telson (Fig. 2C). Male telson narrow, longer than broad at base, with slightly concave lateral margins 


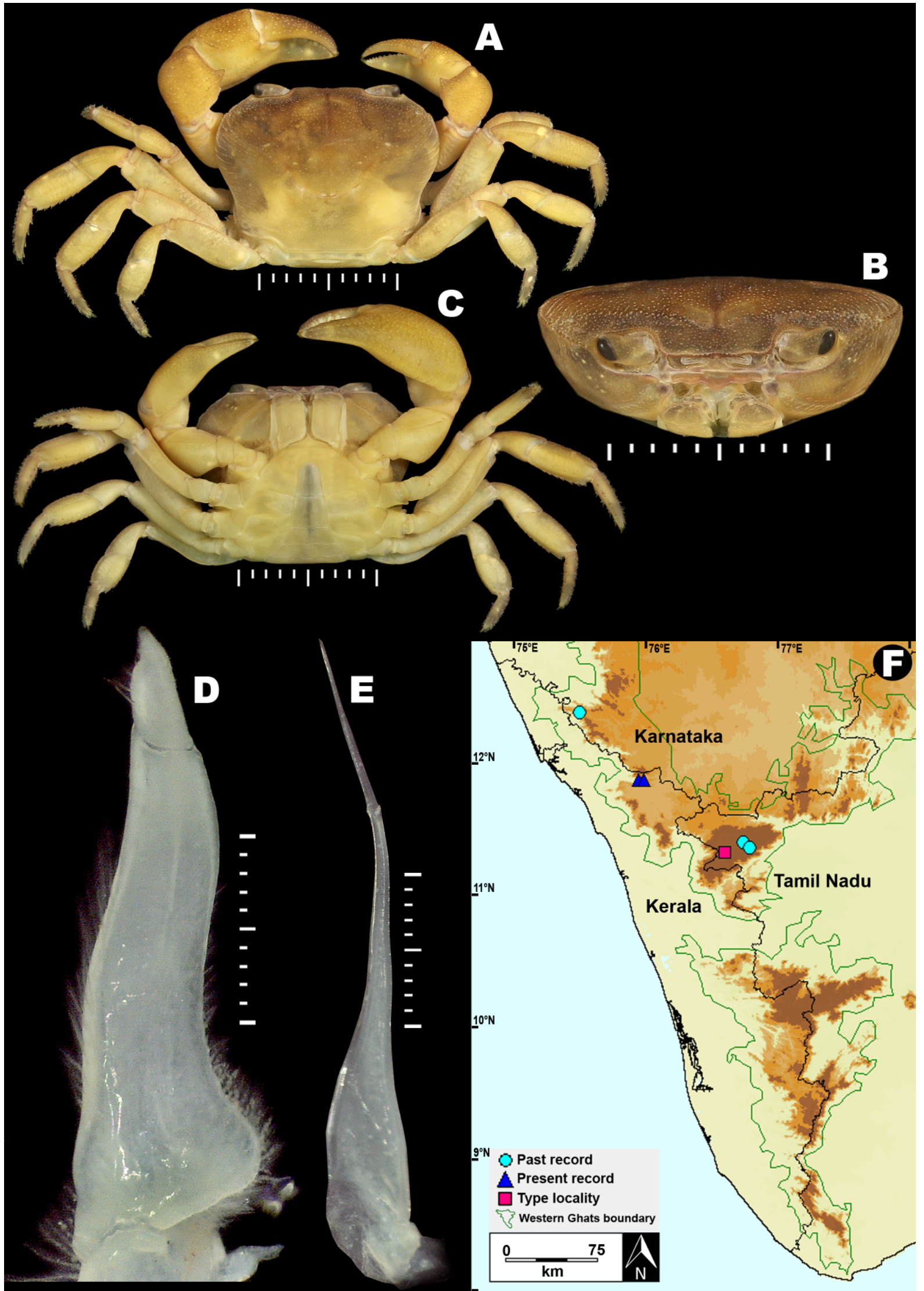

Figure 2. Vanni nilgiriensis (Roux, 1931), male $(15.56 \times 11.35 \mathrm{~mm})($ ZSI-WRC C.1825). A, overall dorsal view; B, frontal view of cephalothorax; C, overall ventral view; D, dorsal view of left G1; E, left G2; F, map showing distribution of $V$. nilgiriensis in the Western Ghats. Scale bar $=10 \mathrm{~mm}(\mathrm{~A}-\mathrm{C}), 1 \mathrm{~mm}(\mathrm{D}, \mathrm{E})$. 
(Fig. 2C). Male sternopleonal cavity short, extending up to imaginary line joining submedian part of cheliped coxae (Fig. 2C). G1 moderately stout, almost straight, with inner margin characteristically curved or angled just below juncture between terminal and subterminal segments; terminal segment almost conical, short, approximately 0.3 times length of subterminal segment, distal third distinctly narrower than basal two-thirds; subterminal segment moderately stout (Fig. 2D). G2 longer than G1, approximately 1.2-1.4 times length of $\mathrm{G} 1$; distal segment long, approximately $0.4-0.5$ times length of basal segment (Fig. 2E).

Remarks. The present specimens of $V$. nilgiriensis from Wayanad district of Kerala are very similar to the male lectotype in carapace morphology. These specimens are relatively smaller (cw 15.56-18.34 $\mathrm{mm}$ ) than the lectotype ( $\mathrm{cw} 24.70 \mathrm{~mm}$ ) and the paralectotype (cw $21.00 \mathrm{~mm}$ ) from Nilgiris of Tamil $\mathrm{Nadu}$. The G2 distal segment in the present specimens, however, is relatively shorter, i.e., approximately 0.4 times the length of the basal segment ( $v s$. relatively long, approximately 0.5 times the length of the basal segment in the lectotype; see Bahir and Yeo, 2007: fig. 35G). In addition, all the present specimens have a relatively shorter G2, approximately 1.2 times the length of the G1 (Fig. 2D, E) (vs. a relatively long G2 in lectotype, approximately 1.4 times the length of $\mathrm{G} 1$; see Bahir and Yeo, 2007: fig. 35C, G). An adult male from Kodagu district of Karnataka (ZSI-WGRC IR/INV/9197) also has a shorter G2 distal segment (approximately 0.4 times the length of the basal segment) like that of the present specimens from Kerala. The lone specimen from Karnataka, however, differs from the present specimens in the length of the G2, which is about 1.3 times the length of the G1. Despite these variations in the G2 of $V$.nilgiriensis, all the present specimens from Kerala and the material from Karnataka are conspecific with the lectotype from Tamil Nadu due to the similarity in overall carapace physiognomy and G1 structure. Although information on variations in G2 structure is unavailable for $V$. nilgiriensis and its congeners, some species (e.g., Travancoriana schirnerae Bott, 1969) of the morphologically related genus, Travancoriana Bott, 1969, depict intraspecific variations in the length of the G2 distal segment (Bahir and Yeo, 2007).
Geographical distribution. Vanni nilgiriensis is currently known from the Western Ghats of Karnataka (Kodagu district), Kerala (Wayanad district), and Tamil Nadu (Nilgiris district) (Fig. 2F). Both the Coorg plateau (the Western Ghats part of Kodagu district) and Wayanad plateau are connected with each other and the Nilgiri mountains, which all together form a continuous mountain chain with similar zoogeography (Bhimachar, 1945). Vanni nilgiriensis is probably restricted to these mountain ranges.

\section{ACKNOWLEDgementS}

The authors are grateful to Dr. Kailash Chandra (Director, Zoological Survey of India, Kolkata) for research facilities. We thank the authorities of the Kerala Forest and Wildlife Department for the survey permit. The second author (PSS) sincerely thanks the Council of Scientific and Industrial Research, New Delhi for her fellowship [Grant No. 08/659(0001)/2017-EMR-I dated 17.07.2017]. We gratefully acknowledge, Dr. Peter Ng (National University of Singapore), Dr. Célio Magalhães (Associate Editor, Nauplius), and an anonymous reviewer for their constructive comments and valuable suggestions.

\section{References}

Alcock, A. 1910. Catalogue of the Indian decapod Crustacea in the collection of the Indian Museum. Part I. Brachyura. Fasciculus II. The Indian fresh-water crabs-Potamonidae. Calcutta, Indian Museum, 135p.

Bahir, M.M. and Yeo, D.C.J. 2005. A revision of the genus Oziotelphusa Müller, 1887 (Crustacea: Decapoda: Parathelphusidae), with descriptions of eight new species. Raffles Bulletin of Zoology, Supplement 12: 77-120.

Bahir, M.M. and Yeo, D.C.J. 2007. The gecarcinucid freshwater crabs of southern India (Crustacea: Decapoda: Brachyura). Raffles Bulletin of Zoology, Supplement 16: 309-354.

Bhimachar, B.S. 1945. Zoogeographical divisions of the Western Ghats, as evidenced by the distribution of hill-stream fishes. Current Science, 14: 12-16.

Bott, R. 1970a. Die Süßwasserkrabben von Europa, Asien, Australien und ihre Stammesgeschichte. Eine Revision der Potamoidea und Parathelphusoidea (Crustacea, Decapoda). Abhandlungen der Senckenbergischen Naturforschenden Gesellschaft, 526: 1-338.

Bott, R. 1970b. Betrachtungen über die Entwicklungsgeschichte und Verbreitung der Süsswasser-Krabben nach der Sammlung des Naturhistorischen Museums in Genf/Schweiz. Revue Suisse de Zoologie, 77: 327-344. 
Davie, P.J.F.; Guinot, D. and Ng, P.K.L. 2015. Anatomy and functional morphology of Brachyura. p. 11-163. In: P. Castro; P.J.F. Davie; D. Guinot; F.R. Schram and J.C. von Vaupel Klein (eds), Treatise on Zoology - Anatomy, Taxonomy, Biology. The Crustacea. Volume 9 (Part C-I). Decapoda: Brachyura (Part 1). Leiden, Brill.

Dev Roy, M.K. 2012. Freshwater crab (Crustacea: Brachyura) diversity in five states of west coast of India. Journal of Environment and Sociobiology, 9: 187-190.

Klaus, S.; Fernandez, K. and Yeo, D.C.J. 2014. Phylogeny of the freshwater crabs of the Western Ghats (Brachyura, Gecarcinucidae). Zoologica Scripta, 43: 651-660.

Kumar, A.B.; Raj, S. and Ng, P.K.L. 2017. Description of a new genus and new species of a fully arboreal crab (Decapoda: Brachyura: Gecarcinucidae) from the Western Ghats, India, with notes on the ecology of arboreal crabs. Journal of Crustacean Biology, 37: 157-167.

Kuriakose, G. and Sebastian, J. 2016. History, biogeography, biodiversity and bioprospecting: scenario from the Western Ghats. South Indian Journal of Biological Sciences, 2: 292-301.

Mitra, S. and Waikhom, M.D. 2019. A new species of freshwater crab of the genus Potamiscus Alcock, 1909 (Crustacea: Brachyura: Potamidae: Potamiscinae) from Manipur, NorthEastern India. Journal of Emerging Technologies and Innovative Research, 6: 624-634.

Mitra, S.; Payra, A. and Chandra, K. 2018. A new species of freshwater crab of the genus Teretamon Yeo \& Ng, 2007 (Decapoda: Brachyura: Potamidae) from Arunachal Pradesh, northeastern India. Zootaxa, 4500: 587-595.

Ng, P.K.L. 1988. The freshwater crabs of Peninsular Malaysia and Singapore. Singapore, Department of Zoology, National University of Singapore, Shinglee Press, 156p.

Ng, P.K.L.; Guinot, D. and Davie, P.J.F. 2008. Systema Brachyurorum: Part I. An annotated checklist of extant brachyuran crabs of the world. Raffles Bulletin of Zoology, Supplement 17: 1-286.

Pati, S.K. and Sharma, R.M. 2012a. Freshwater crabs of some protected areas and wetlands, Maharashtra. Bionotes, 14: 126-127.

Pati, S.K. and Sharma, R.M. 2012b. Freshwater crabs (Gecarcinucidae: Brachyura: Decapoda). p. 365-366. In: The Director (ed), Fauna of Maharashtra, State Fauna Series 20 (Part-2). Kolkata, Zoological Survey of India.

Pati, S.K. and Sharma, R.M. 2013. A new species of freshwater crab, Travancoriana granulata n. sp. (Brachyura: Gecarcinucidae) from the southern Western Ghats of India. Zoosystematics and Evolution, 89: 275-281.

Pati, S.K. and Sharma, R.M. 2014. Freshwater crabs (Crustacea: Decapoda: Brachyura: Gecarcinucidae) in the collection of the Western Regional Centre, Pune. Records of the Zoological Survey of India, Occasional Paper, 363: 1-44.

Pati, S.K. and Sudha Devi, A.R. 2015a. Description of a new genus and new species of freshwater crab (Brachyura: Gecarcinucidae) from the Western Ghats, Kerala, India. Zoological Studies, 54: 35.

Pati, S.K. and Sudha Devi, A.R. 2015b. Spiralothelphusa gibberosa, a new freshwater crab (Brachyura: Gecarcinucidae) from Thrissur district, Kerala, India. Zootaxa, 3963: 416-424.

Pati, S.K. and Thackeray, T. 2018. The freshwater crab genera Ghatiana Pati \& Sharma, Gubernatoriana Bott, and Inglethelphusa Bott (Crustacea: Decapoda: Brachyura: Gecarcinucidae) revisited, with descriptions of a new genus and eleven new species. Zootaxa, 4440: 1-73.

Pati, S.K.; Rajesh, L.; Raj, S.; Sheeja, V.U.; Kumar, A.B. and Sureshan, P.M. 2017. Karkata, a new genus of gecarcinucid freshwater crab with two new species, and four new species of Pilarta Bahir and Yeo, 2007 and Cylindrotelphusa Alcock, 1909 (Decapoda: Brachyura) from Kerala, India. Journal of Natural History, 51: 1295-1330.

Rajesh, L.; Raj, S.; Pati, S.K. and Kumar, A.B. 2017. The freshwater crabs (Decapoda: Brachyura) of Kerala, India. Journal of Aquatic Biology \& Fisheries, 5: 132-153.

Rathbun, M.J. 1904. Les crabes d'eau douce (Potamonidae). Nouvelles Archives du Muséum d'Histoire Naturelle, Paris, Series 4, 6: 225-312.

Roux, J. 1931. Crustacés Décapodes d'eau douce de l'Inde méridionale. Revue Suisse de Zoologie, 38: 31-62.

Srivastava, O.P. 2007. Crustacea: Brachyura: Crabs. p. 33-37. In: The Director (ed), Fauna of Bannerghatta National Park, Conservation Area Series 33. Kolkata, Zoological Survey of India.

Srivastava, O.P. 2009. Crustacea: Decapoda: Gecarcinucidae. p. 29-30. In: The Director (ed), Fauna of Tamil Nadu, State Fauna Series 17 (Part-1). Kolkata, Zoological Survey of India.

Srivastava, O.P. 2013. Crustacea : Decapoda : Gecarcinucidae (Freshwater and Land Crabs). p. 73-78. In: The Director (ed), Fauna of Karnataka, State Fauna Series 21. Kolkata, Zoological Survey of India. 